\title{
Effect of extraction Alkaloids from Zephyranthes candida induces cell death through destruction microtubules in (China hamster cell line) IsraaTareqAakool AL-Zerkani (MSc) ${ }^{1}$
}

\begin{abstract}
Background: In eukaryotic cells the cytoskeleton network consists of three major structural elements, microtubules, microfilament,and intermediate filaments. Tubulin is the basic protein of the MTs, molecules of tubulin arranged in dimmers consisting of two forms, $\alpha$ tubulin and $\beta$-tubulin. They are continuously changeable structures.Taxanes and vinca alkaloids are inhibitors MTC that destabilize microtubules, there by suppressing their dynamics which required for proper mitotic function and effectively blocking cell regulation progression resulting in cell death.

Objective: To evaluate the capability of alkaloids taken away from leaves of Zephyranthes candidato divert the MTC network of (CHO), which is an aggressive metastasis cell line. Patients and Methods: In our experiments we used the mouse $\mathrm{CHO}$ cell line. This cell line was obtained from the Department of Biology,Faculty of Medicine, Wuhan University, China. The cells were grown in Dulbecco's Minimal Essential Medium (DMEM) (PAA Laboratories $\mathrm{GmbH}$, Linz, Austria), supplemented with 10\% fetal bovine serum, $2 \mathrm{mM}$ glutamine, $100 \mathrm{Uml}-1$ penicillin, and $100 \mu \mathrm{g}$ ml-1 streptomycin (PAA Laboratories, Austria) in a humidified atmosphere of $95 \%$ air and $5 \% \mathrm{CO} 2$ at $37{ }^{\circ} \mathrm{C}$.Zephyranthes candida crude alkaloid extract treated cells were cultivated over microscopic cover slips, washed three Times for 4 min with PBS ( $\mathrm{pH}$ 6.9) and fixed by 3\% paraformaldehydein PBS. The ability of alkaloid extract to inhibit CHO tumor cells growth in vivo was assessed; forty mice were injected subcutaneouslyin the right dorsal with this tumor cells, after the tumor developed to 8-1 $\mathrm{mm} 2$, and eliminating the animalsthat did not develop tumors, the animals were divided to three groups each one with ten individuals.

Results: The extractor was capable of divert the MTC of the cells below realization after $1 \mathrm{hr}$ of in sinuation in a focus as little as possible $20 \mu \mathrm{g} / \mathrm{ml}$. while DAPI staining used, the cells death was not check in this focus and time. The cell death have been spotted when the focus of the alkaloid reproducer raised up to 80 and $100 \mu \mathrm{g} / \mathrm{ml}$ through the aforesaid exposure time. The cells were able to improving there native MTC contraction after $12 \mathrm{hr}$ of the alkaloid deletion. The excerpt focus of $1 \mathrm{mg} / \mathrm{Kg} / \mathrm{Bw}$ competently prevent $\mathrm{CHO}$ cell line cancer development in vivo to $97.14 \%$ after 3 weeks therapy contrast to natural control.

Conclusion: The invasive species H22 cells offer changesin the preparation of their MTC at a focus of Zephyranthes candida leaf alkaloids excerpt as low as $20 \mu \mathrm{g} / \mathrm{ml}$ focus after $1 \mathrm{hr}$ of exposuretime.
\end{abstract}

Key words: Cytoskeletal, Microtubules, Alkaloids ,Zephyranthes candida.

Corresponding Author: israairaqi46@gmail.com

Received: $22^{\text {th }}$ October 2017

Accepted: $14^{\text {th }}$ November 2017

https://doi.org/10.26505/DJM

${ }^{1}$ College of Scince- Diyala University- Diyala -Iraq. 
Effect of extraction Alkaloids from Zephyranthes candida induces cell death through destruction microtubules in

\section{Introduction}

In eukaryotic cells the cytoskeleton network consists of three major structural elements, microtubules, microfilament,and intermediate filaments (1). This network plays specific role in cell division, intracellular contacts, interaction with membranes, extracellular matrix, cell motion and maintenance or changes of cell shape (2). The diameter of microtubules (MTs) is about $25 \mathrm{~nm}$ they are composed of 13 equally spaced pro-filaments (2). Tubulin is the basic protein of the MTs, molecules of tubulin arranged in dimmers consisting of two forms, $\alpha$ - tubulin and $\beta$-tubulin. They are continuously changeable structures (3), polymerization and depolymerization of MTs is regulated by extra and intra-cellular factors (4). The presence of GTP at MTs ends is necessary to maintain the stability of the polymer (5). Because of their key role in cell function, microtubules emerged as important targets for cancer therapy. Taxanes and vinca alkaloids are microtubule inhibitors that destabilize MTC, there bysuppressing their dynamics which required for proper mitotic function and effectively blocking cell cycle progression resulting in cell death. In spite of their antitumor activity, drug resistance to such MTs inhibitors is common, limiting their overall clinical efficacy. Therefore the discovery of novel agents that may overcome resistance to conventional MTs inhibitors and provide higher efficacy of microtubuletargeting with limited toxicity is actually need (6). In addition, despite the success of vinca alkaloids taxanes to inhibit the progression of some cancers in clinical use, resistance to antimicrotubule agents is encountered in many tumor types, particularly during multiple cycles of therapy. Therefore, there has been great interest in identifying and developing novel anti-microtubule drugs. (7) the most widely used alkaloid like vinbkastne, often induce some intractableside effects including neurological toxicities and in particular, experience with both acquiredis focusing on the development of new semi synthetic Vinca alkaloids, with the aim of overcoming current restrictions. The vindoline coupled with catharanthine were chemically manipulated in an effort towards the finding of the promising therapeutics. Of that BM6 stood out as the most potent new Vinca alkaloids derivative. In comparison with classical Vinca alkaloids, BM6 had its distinct antitumor activities in vivo due to its better pharmacokinetics profiles and its more specificity towards tubulin (8). products Natural have provided key leads for drug discovery.Many interesting biological properties have been characterized for novel natural products. Alkaloids are a large group of secondary metabolites containing usually basic nitrogen derived from amino acids, purines, pyrimidine or other source such as transamination (9). classified alkaloids chemically according to the nitrogencontaining ring system. (10).Zephyranthescandidaisglastum is flowering plant it is commonly called dyers woad .woad is native to the steppe and desertZones of the Caucasus, (11). On the contrary to the species Zephyranthes 
Effect of extraction Alkaloids from Zephyranthes candida induces cell death through destruction microtubules in (China hamster cell line) Israa Tareq Aakool AL-Zerkani

candidawhich is understood to contain alkaloids that appear nontoxic in animal studies and have potent tumor-inhibitory effects and anti-angiogenetic effects (12) (13) (14). The alkaloids of the species are not yet investigated. This study is the first to assess the activity of locally harvestedZephyranthes candidaalkaloids against the microtubules of aggressive micecell line $\mathrm{CHO}$ and induction ofapoptosis.

\section{Patients and Methods}

The plat used in these experimentations was collected from gardens in Daiyla Figure (1).

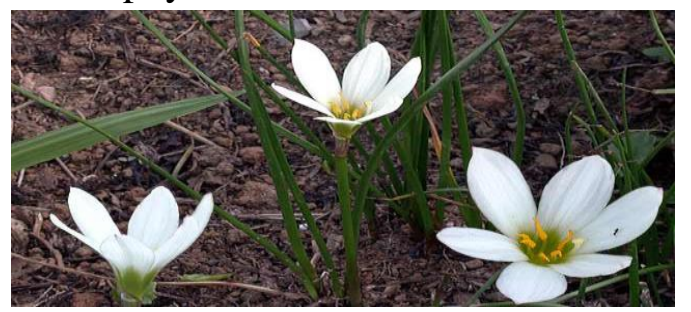

Figure(1):Zephyranthes candida

Alkaloid extraction: alkaloids extraction from the flower of this plant was extracted as described by (15) and 16).

\section{Cell line}

In our experiments we used the mouse CHOcell line. This cell line was obtained from the Department of Biology,Faculty of Medicine, Wuhan University, China. The cells were grown in Dulbecco's Minimal Essential Medium (DMEM) (PAA Laboratories $\mathrm{GmbH}$, Linz, Austria), supplemented with $10 \%$ fetal bovine serum, $2 \mathrm{mM}$ glutamine, $100 \mathrm{Uml}-1$ penicillin, and $100 \mu \mathrm{g} \quad \mathrm{ml}-1$ streptomycin (PAA Laboratories, Austria) in a humidified atmosphere of $95 \%$ air and $5 \% \mathrm{CO} 2$ at 37 ${ }^{\circ} \mathrm{C}$.

Characterization of invasive and metastasis properties in vivo: For invasive assay, group of five mice were injected in the intraperitoneal cavity with H22tumor cells and observation for ascites formation was conducted through cavity volume measurement. For the evaluation of metastatic potential mouse bone metastatic model was adopted, a group of five mice were injected with $\mathrm{H} 22$ tumor cells in the right leg muscle. After tumor development, right femur (the nearest boon) was extracted and evaluated morphologically (differences between normal and abnormal bone shape).Exposure to Crude Alkaloid extract In order to assess the kinetics and mechanism of Zephyranthes candidacrude alkaloid extract effect on the MTs network of the cell line under investigation, three sets of experiments were conducted.In the first experiments, three different concentrations setswere used, sub-one hundred $(20,40,80,100 \mu \mathrm{g} / \mathrm{ml})$, over one hundred $(200,400,800 \mu \mathrm{g} / \mathrm{ml})$, and over one thousand $(4000 \mu \mathrm{g} / \mathrm{ml}$ and 9000 $\mu \mathrm{g} / \mathrm{ml}$ ), the crud alkaloids was prepared in 1 $\mathrm{ml}$ of $2 \%$ SDS. The cells were exposed to the prepared solutions for $60 \mathrm{~min}$ at $37^{\circ} \mathrm{C}$. Each concentration was tested in two replicates, the control samples were exposed to phosphate-buffered saline (PBS, pH 6.9). In the second experiment, the cells were 
exposed to finalcrude alkaloid concentration $20 \mu \mathrm{g} / \mathrm{ml}$ for 15,30 , and 60 minutes at $37^{\circ} \mathrm{C}$ in DMEM media. Cells were also treated for 5 minutes in a medium containing alkaloids at a concentration of $800 \mu \mathrm{g} / \mathrm{L}$. control samples were treated with $\mathrm{PBS}(\mathrm{pH}$ 6.9).The third series of experiments was performed with the crude alkaloid extract at a final concentration of $20 \mu \mathrm{g} / \mathrm{ml}$ for $60 \mathrm{~min}$. After the time of the treatment was over, the drugcontaining medium was poured off and cells were subjected to three washings with PBS (pH 6.9). Plates were refilled with fresh growth medium and incubated for another 6 , 7,8, 9 and 12 hour in order to evaluate the recovery processes. Recovery progressed at $37{ }^{\circ} \mathrm{C}$ in a humidified atmosphere of $95 \%$ air and $5 \% \mathrm{CO} 2$.

Visualization of microtubules network: Zephyranthes candidacrude alkaloid extract treated cellswere cultivated over microscopic cover slips, washed three times for $4 \mathrm{~min}$ with PBS (pH 6.9) and fixed by $3 \%$ paraformaldehydein PBS. Thereafter, the cells were permeabilised by $0.2 \%$ Triton X100 solution in PBS. The microtubules weredetected by means of the mice antitubulin monoclonal antibodyTU-01 (Institute of Molecular Genetics, Prague, CzechRepublic), diluted 1:300 by PBS, and a secondary swine antimouse IgG conjugated with TaxesRed (TR) or conjugatedwith green florescent protein (SwAM/TR,GFP ;Institute forSera and Vaccines, Prague, Czech Republic) diluted 1:100 byPBS. Cells were washed with phosphate buffer three timesfor 5 min between the applications of individual agents. Thesamples were then closed in the Vectashield mounting medium(Vector Laboratories, Inc., Burlingham, CA, USA) andvisualized with fluorescent microscope.Staining with 4,6 -diamidino -2phenylindole (DAPI)In order to assess the incidences of DNA condensation as anindicator of apoptosis, treated and control cells was stainedwith DAPI.

Antitumor activity in vivo: The ability of alkaloid extract to inhibit $\mathrm{CHO}$ tumor cellsgrowth in vivo was assessed; forty mice were injected subcutaneouslyin the right dorsal with this tumor cells, after thetumor developed to 8-1 $\mathrm{mm} 2$, and eliminating the animalsthat did not develop tumors, the animals were divided tothree groups each one with ten individuals (of each group,five animals served as control untreated and five animals wastreated with the alkaloid extract). the treated animals in eachgroup was injected four time a week (every other day) subcutaneouslywith $1 \mathrm{mg} / \mathrm{Kg} / \mathrm{Bw}$ for deferent period oftime.The treatment dose was determined according to the LD50(data not shown) of the crud alkaloid extract. The first groupinjected with the alkaloid for one week, the second groupfor two weeks, and the third group for three weeks.

\section{Statistical Analysis}

The controlanimals of the three groups were injected subcutaneouslywith DMSO.After the treatment times were over, animals were sacrificedand tumors were extracted and tumor mass was determinedaccording to the relation $\mathrm{Tv}=\mathrm{L}(\mathrm{W}) 2 / 2$, where $\mathrm{Tv}=$ Tumorvolume, $\mathrm{L}=$ 
Effect of extraction Alkaloids from Zephyranthes candida induces cell death through destruction microtubules in (China hamster cell line) Israa Tareq Aakool AL-Zerkani

Length of tumor, and $\mathrm{W}=$ Width of tumor.Tumor growth inhibition was calculated accordingto the relation $\mathrm{GI} \%=$ (A-B/A)100, where GI = Growthinhibition, $\mathrm{A}=$ tumor volume in untreated animals, and $\mathrm{B}=$ Tumor volume in treated animals.

\section{Results}

Under the cell line realization was defined to an invasive species and metastasis (17). The cell was experience in vivo with metastasis, this was underline when the cancer cell added in the leg of a some of mice. The cancer cells were able to grow a secondary bone cancer in the right femur of the injected animals only after 1 week (Figure 1, A, B, C.). The aggressiveness of theH22 cells was truculence, the cancer cells was able to make tumor pointedly after 2 days of in traperitoneal injection (Figurer 1, D).Bright field fluorescent microscope ,the used fluorescent dyestains the cell nuclei with green color .The MTC of natural control cells (Figure 3) display network orderly dispersed along the complete cell content
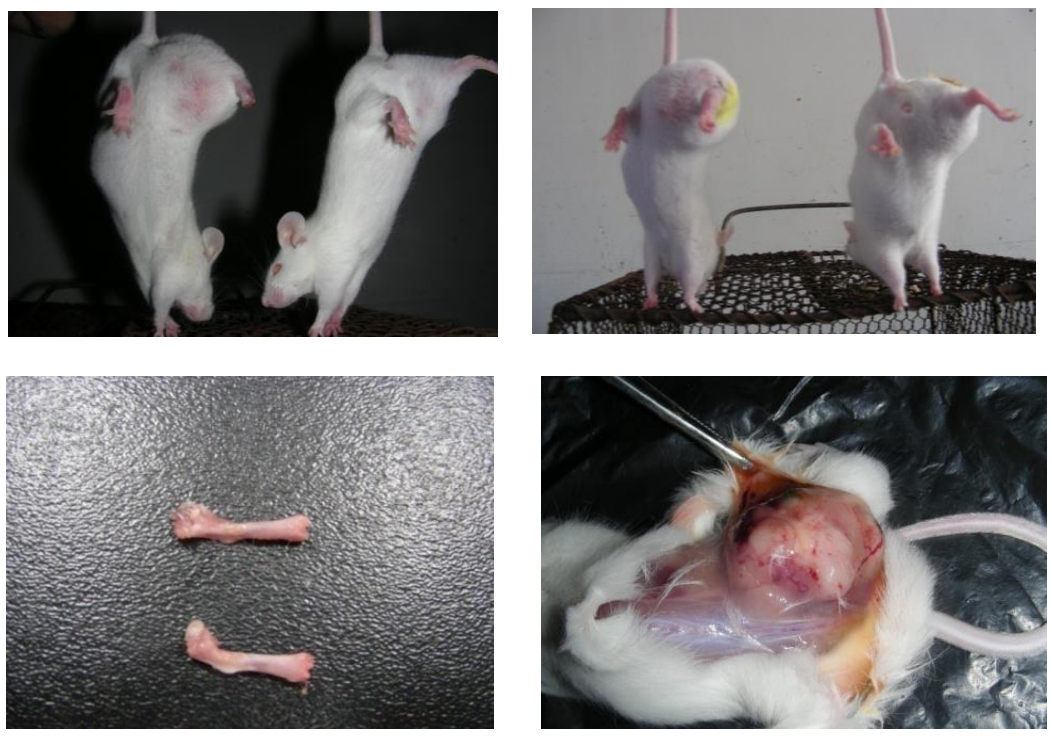

Figure(1):The CHO cells were injected subcutaneously in the right leg of mice. A and B; tumor development.C; right femur deformation after secondary bone tumor formation after one week of injection.D; ascites tumor formation only solid after three week of intraperitonealinjectionin the mice

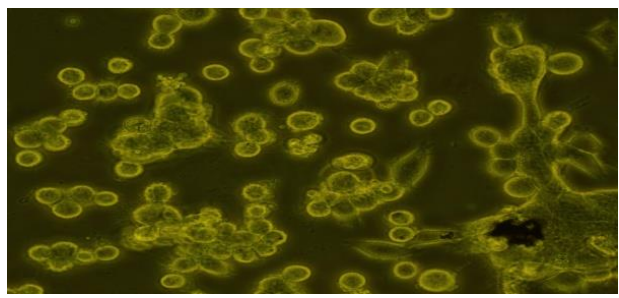

Figure(2): CHO cell line photograph in bright fielded microscopic . 


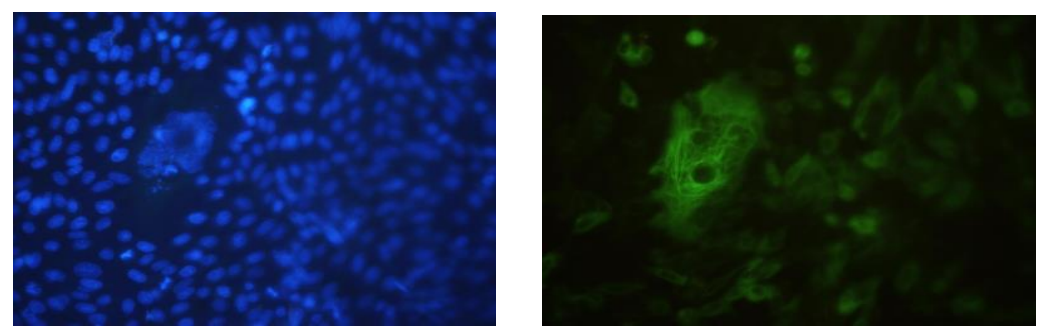

Figure(3): Visualizing CHOcells microtubules: untreated cells (control) and stained with secondary GFP conjugated swine anti-mouse IgG (upper panel), nucleistained with DAPI(lower panel).

When ells exposed to alkaloid crude showed changes in the arrangement of the extract from leaves of Zephyranthes MTC network (Figures 4 and 5). The candidaat concentrations from 2 to $10 \mu \mathrm{g} /$ network of cytoplasm MTC at the lowest $\mathrm{ml}$ for $60 \mathrm{~min}$, it did not show considerable changes in thedistribution of MTC (data not shown). Cells exposed to concentrations of $20,40,80,100,200$, 400 , and $800 \mu \mathrm{g} / \mathrm{ml}$ for $60 \mathrm{~min}$ they concentration used $(20 \mu \mathrm{g} / \mathrm{ml})$ was clearly and obviously thinned down, and the treatedcell individual MTCfibers had a destructed and granulated wavelike shape.
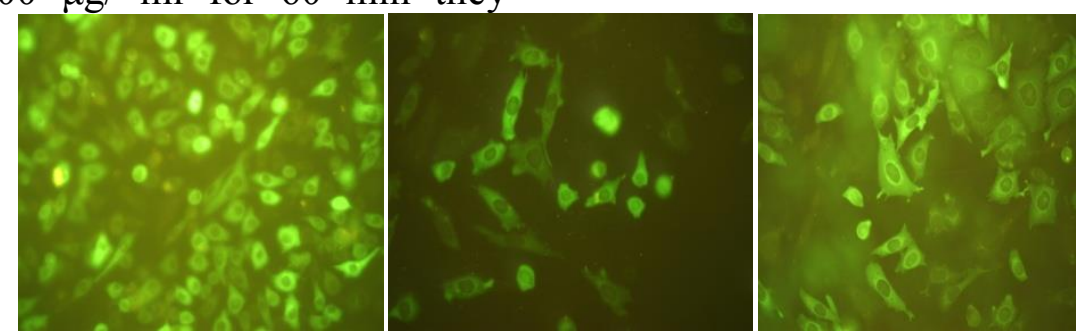

Figure(4): CHO cells treated with different sub-one hundred concentrations ofZephyranthes candidaAlkaloid extract as indicated for $60 \mathrm{~min}$. is a representative microscopicfields).
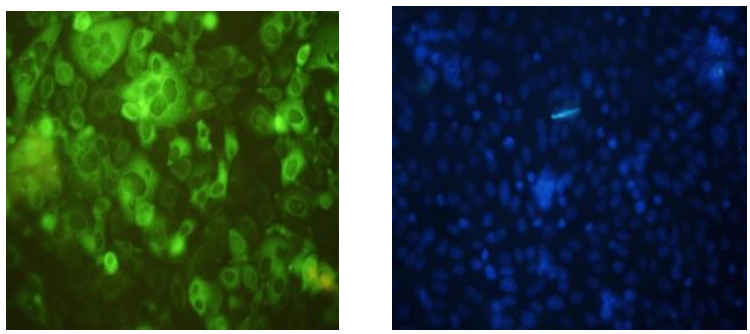

Figure(5): $\mathrm{CHO}$ cells treated with different over-one hundred concentrations of Zephyranthes candida lkaloid extract as indicated for $60 \mathrm{~min}$.

The network damage increased with the increasing of Zephyranthes candida alkaloid extract concentration from 20 to $800 \mu \mathrm{g} / \mathrm{ml}$. In these concentrations DNA fragmentation was observed in the treated cells as indicated by DAPI staining cells.
The microtubules were more thinned down and fragmentation of microtubule fibers occurred at a higher concentration of alkaloid extract (4000 and 9000 $\mu \mathrm{g} / \mathrm{ml}$ ), sometimes blebs were formed in this elevated concentration and DNA 
Effect of extraction Alkaloids from Zephyranthes candida induces cell death through destruction microtubules in (China hamster cell line)

Israa Tareq Aakool AL-Zerkani

fragmentation was indicated (Figure 6).When cells were exposed to alkaloid at a concentration of $20 \mu \mathrm{g} / \mathrm{l}$ for $2,5,10,15$ or 20 minutes, no noticeable changes occurred in the microtubule network (data not shown). The $30 \mathrm{~min}$ treatment at concentration of $20 \mu \mathrm{g} / \mathrm{ml}$ did not cause an obvious disruption of the treated cell microtubules Figure (7).When exposed toZephyranthes candida alkaloid extract at a concentration of $800 \mu \mathrm{g} / \mathrm{ml}$ for 5 minutes, the treated cells showed a severely defected microtubules network. In this time and concentration the network was thinned down, and singular fibers had a granulated wavelike shape Figure (8). In the microtubules recovery experiments, all the cells with the recovering period of 6 hours in a drug-free growth medium followingZephyranthes candidaalkaloid extract exposure,showed no recovered but damaged microtubules. The cells after 7 hours recovery period had their microtubules network either partially restored or still damaged. After recovery for an 8 hours period, some cells showed a partially defective (thinneddown) network, but the majority of the cells showed restored microtubules Figure (9). When the cells were allowed to recover for 9 hours, the microtubules was also damaged, only several cells showed nearly restored microtubules. After a recovery period of 12 hours, microtubules were spread out comparably to those observed in untreated control cells Figure (9). The control cells showed their microtubule network regularly distributed along the whole cell volume.
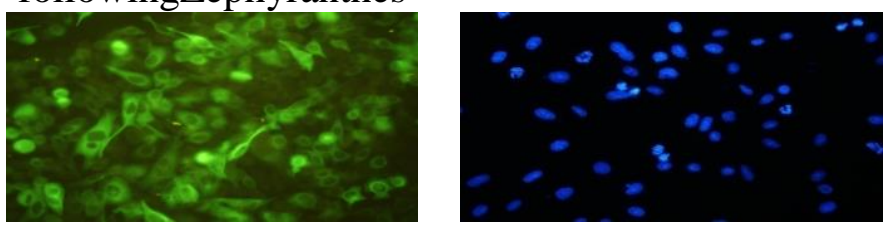

Figure(6): $\mathrm{CHO}$ cells treated with $20 \mu \mathrm{g} / \mathrm{ml}$ ofZephyranthes candidaalkaloid extract as indicated for $30 \mathrm{~min}$. Stained with secondary GFP conjugated swine antimouseIgG (middle panels).Nuclei stained with DAPI (lower panels).
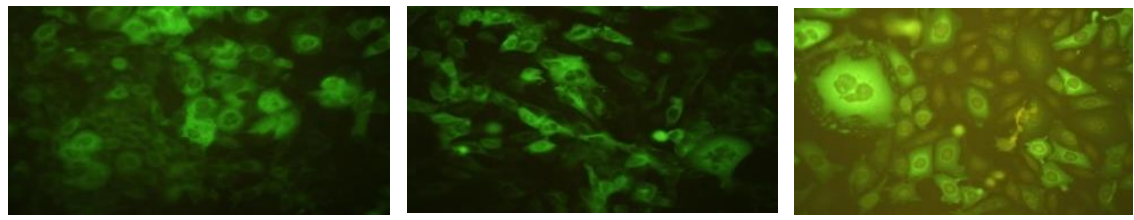

Figure(7): CHOcells treated with $800 \mu \mathrm{g} / \mathrm{ml}$ ofZephyranthes candidaalkaloid extract as indicated for 5 min. stainedwith secondary GFP conjugated swine anti-mouse IgG.
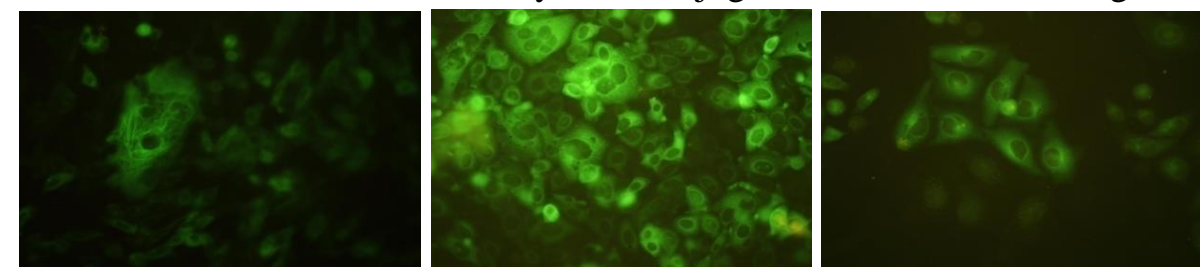

Figure(8): $\mathrm{CHO}$ cells treated with $20 \mu \mathrm{g} / \mathrm{ml}$ ofZephyranthes candidaalkaloid extract as indicated for $60 \mathrm{~min}$ as indicated in the methods and recovered with fresh media for 6, 7 and $8 \mathrm{hr}$, stained with secondary GFP conjugated. 
Effect of extraction Alkaloids from Zephyranthes candida induces cell death through destruction microtubules in (China hamster cell line) Israa Tareq Aakool AL-Zerkani

The antitumor activity of the crude alkaloid extract ofZephyranthes candidaleafs in vivo was considerably substantial,the tumor volume was reduced segnificaqntly $(<0.01)$ ten times after only two week of crude alkaloid extract treatment,andsegnificaqntly $\quad(<0.01)$ thefive times after three weeks of alkaloid treatment figure (10). The alkaloid

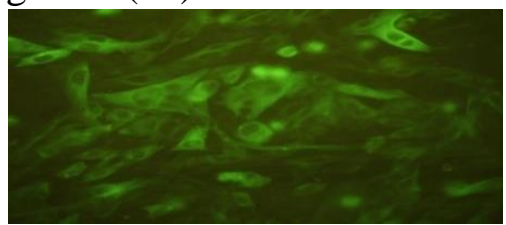

extracttumor gruoth inhibition ablity reached almost $95 \%$ of that in control untreated animels figure $(11 \& 12)$. Ahugedefferences (segnificaqnt $<0.01$ ) were observed in tumor mass between treated and nontreated control animals after three weeks of $1 \mathrm{mg} / \mathrm{Kg} /$ Bwadminstration figure (13).

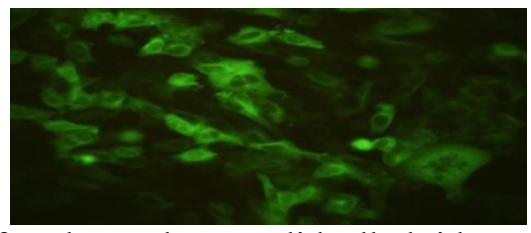

Figure(9): $\mathrm{CHO}$ cells treated with $20 \mu \mathrm{g} / \mathrm{ml}$ ofZephyranthes candidaalkaloid extract for 60 as indicated in the methods and recovered with fresh media for $9 \mathrm{hr}$ and $12 \mathrm{hr}$.

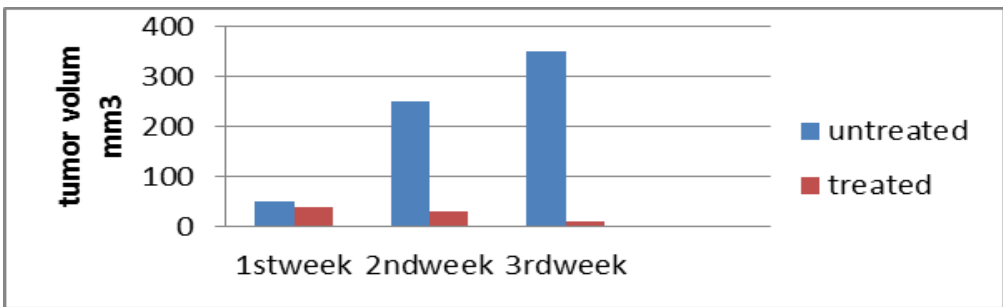

Figure(10): Tumor volume in mice treated with Zephyranthes candidaalkaloid extract of for deferent periods of time compared to untreated control mice.

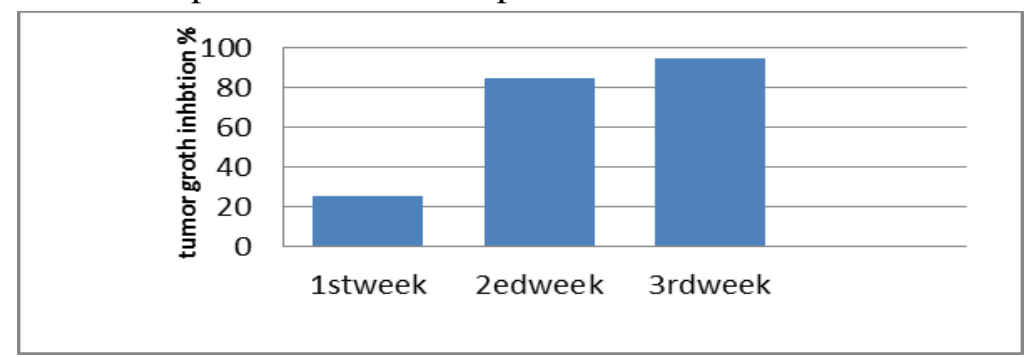

Figure(11): Tumor growth inhibition percentage in mice treated with the alkaloid extract ofTerbuluesterrestrisdurring the three different time of administration in vivo.
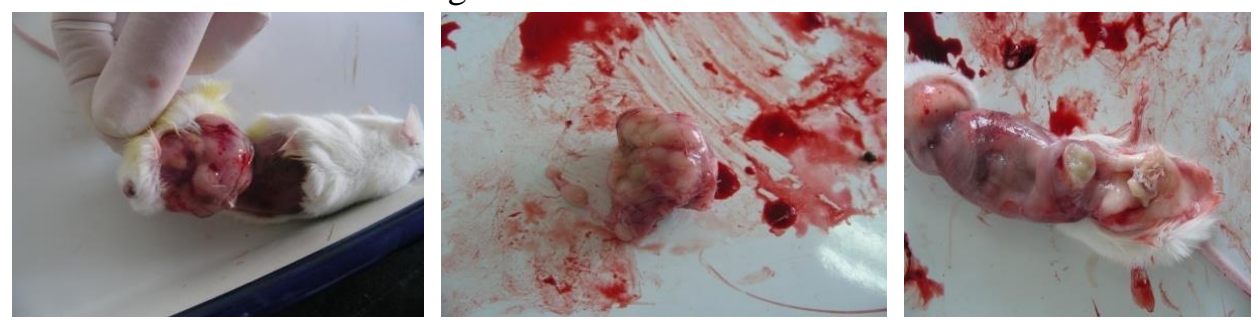

Figure(12): Antitumor activity ofZephyranthes candidaalkaloid extract, animals was injected for four times a week with $1 \mathrm{mg} / \mathrm{Kg} / \mathrm{Bw}$ for $\mathrm{A}$; one week treatment, $\mathrm{B}$; two weeks treatment $\mathrm{C}$; three weeks treatment. Upper row is for untreated control animals and lower row is for treated animals. 


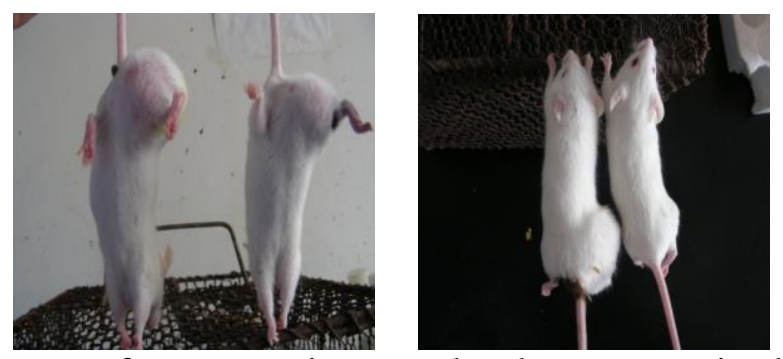

Figure(13): the appearance of representativecontrol and treatmentanimals of group three (after threeweeks of $1 \mathrm{mg} / \mathrm{Kg} / \mathrm{Bw}$ crude alkaloidextraction administration).

The antitumor activity of the crude alkaloid extract of Zephyranthes candida leafs in vivo was considerably substantial,the tumor volume was reduced segnificaqntly $(<$ 0.01)ten times after only two week of crude alkaloid extract treatment,and segnificaqntly $(<0.01)$ the rtifive times after three weeks of alkaloid treatment figure (10). The alkaloid extract tumor growth inhibition ablity reached almost $95 \%$ of that in control untreated animels figure(11\&12). Ahugeefferences(segnificaqnt $<0.01$ ) were observed in tumor mass between treated and nontreated control animals after three weeks of $1 \mathrm{mg} / \mathrm{Kg} / \mathrm{B}$ wadminstration figure (13).

\section{Discussion}

Interaction of antitumor agents with components of the cytoskeleton is a theme studied in many researches (5-12). Targeting cancer cells microtubules is one of many strategiesutilized to defeat deferent types of this disease (17). Natural products were of the realist chemicals to be recognized as potent antitumor drugs as a result of their interaction withcancer cells microtubules (18-26). The cell line under this study was highly invasive and metastatic, its ability to induce ascites tumor in the peritoneal cavity of the mice after 48 hrafter its injection indicted such conclusion. Moreover when it injected in the right leg of mice group, it metastasized to the nearest boon (femur) in period of one week in all individual alsof the injected animals. The huge femur boon morphological deformations in the injected animals were clearly indicted as a result of boon tumor formation. These in vivo results confirm what have been characterized about this cell line in in vitro experiments, it was found that these cells can detached from the mother tumor nuclide to invade basement membrane and extracellular matrix by adhering to fibronectin for movement and migration, thus leading to tumor diffusion and metastasis. It metastasized to the lung when injected intravenously (27).Phytochemicals such as alkaloids compounds elicit various biological effects including cancer chemoprevention and treatment (28). Kimet al(14) studied the effect and action mechanisms of tryAqueous extraction on murine myloid leukemia cells interaction of alkaloids with tubulin, and compared alkaloid and aqueous extract from leaves of Zephyranthes candida. He studied the affinity of the drug to tubulin heterodimers and apoptosis. Alkaloid exhibited a higher overall affinity for porcine brain tubulin than aqueous extracts. Under the present experimental conditions, a similar affinity was marked. The 20 concentration used in this study indicates a specific affinity of the to this invasive cell line.The minimum time required for thisconcentration to induce microtubules deformation was $60 \mathrm{~min}$, where it induces no effect in exposure time less than 
that. Elevating the concentration to 800 shortened the time needed to induce microtubules deformation in this cell line down to 5 minute. All these results indicated the specific targeting of the microtubules by alkaloid extract of leafs Zephyranthes candida. Cellswith apoptotic characteristics started to appears in alkaloid concentrations started from $100 \mu \mathrm{g} / \mathrm{ml}$ and higher during exposure time $(60 \mathrm{~min})$. This refer to another possible effectermechanism that alkaloid extract exercise towered $\mathrm{H} 22$ cells. Nagappan and co-workers found that Carbazole Alkaloids have antitumor activity with much higher concentration, thesignificant minimum inhibition concentration (MIC) values was 25.0-175.0 $\mathrm{mg} / \mathrm{mL}$ against MCF-7, Hela and P388 cell lines (29). Some authors also studied the recovering processesof the cytoskeleton after treatment of cell cultures with physical factors or agents interfering with cytoskeleton compounds. Alkaloid caused a sequence of morphological change sinsensitive cells from three pleiotropic resistant MCF-7 human breast carcinoma cell lines mixed with vaginal adenocarcinoma cells. The cells were selected in serially increasing drug concentrations. These changes included precipitation of tubulin and disappearance of tubular structure. The changes occurred initially within 3 hours of incubation, but were expressed in all cells after 6 hours. After 3 hours of drug exposure, the cells were sub-cultured in drug-free media, the cells cytoskeletal structure reformed within 10 hours. The maximal recovery of the cytoskeletal structure occurred 22 hours after drug removal and was sustained up to 36 hours (13). Treatment of hippocampus neurons with alkaloid compoundseliminated the microtubule bundles, leaving only tubulin paracrystals.
Within 24 hours after washing out the alkaloid, the microtubule bundles repolymerised in cultured cells (14). In competence with this, alkaloid extract of leafs demonstrate the same mechanism effect on the cell line under this study. Its antitubules effect was eliminated after 10-12 $\mathrm{hr}$ of in vitro cultivation in drug free media.The effect of Zephyranthes candida.the alkaloid extract toward this cancer cells was significant in vivo as well. The used dose was capableto inhibit tumor growth in $26.8 \%, 92.16 \%$ and $97.14 \%$ after one, two and three weeks of treatment respectively compared to nontreated control animals. This explains that action of the alkaloid extract on distraction of microtubules of this cancer cells is active in vivo as well in vitro in addition to other possible mechanisms.

\section{Conclusion}

The invasive $\mathrm{H} 22$ cells offer changes in the configuration of their MTC at a focus Zephyranthes candida leaf alkaloids excerpt as low as possible $20 \mu \mathrm{g} / \mathrm{ml}$ focus after $1 \mathrm{hr}$. Its harm bigger with increase of the alkaloids excerpt focus. Rising exposure dose may lessen the exposure time; disorder of the MTC was also time-needy. The excerpt was able to lessen cancer growth in vivo up to $95 \%$ of control natural animals and prevent cancer development in the treated mice to $97.14 \%$ compared with control natural animals.

\section{References}

[1] Schliwa M. (1986).The Cytoskeleton. An Introductory Survey. Springer-Verlag Wien; 326.

[2]Toshio,N.;Akiko,K.;Yuasa,M.;andDavid, O.(2008).Mechanism of growth of inhibitory effect of blume.Biochem.772:1183-1189. 
[3]Schmidt,M. and Bastians, H. (2007). Mitotic drug target and development of novel anti-mitotic anticancer drugs. Drug Resistance Updates .10: 162-181.

[4] Jordan, M.A. (2002). Mechanism of action of anti tumor drugs that interact microtubules and tubulin, Curr.Med. Chem. Anti-Canc. Agents, 2: 1-17.

[5]Lopus, M.; panda, D. (2006).the enzophenanthridine alkaloid sanguinarine perturbs microtubule assembly dynamic through tubulin binding .A possible mechanism for its antiproliferative activity. J. FEBS. 273: 2139-50.

[6] Perez, E. A. 2009. Microtubule inhibitors: Differentiating tubulin-inhibiting agents based on mechanisms of action,clinical activity, and resistance. Mol. Cancer Ther. 8:2086-95.

[7] Tian, W.; Qin, L.; Song, Q.; He, L.; Ai, M.; Jin, Yi.; Zhou,Z.; You, S.; Long, Yaqiu.; Yu, Q. 2010. A novel syntheticanalog of 5, 8-disubstituted quinazolines blocks mitosis and induces apoptosis of tumor cells by inhibiting microtubule polymerization. PLoS ONE. 5:10499.

[8] Klener P. Protinádorováchemoterapie (1996).Antitumour Chemotherapy. Praha: Galén, 344-348.9. Li ,W.; Lihong, Y. S.; Zhang, H. X.; Chen, Y.; Li, L. T. C.;Shen, X.; Ding, J. 2007. BM6, a new semisynthetic vinca alkaloid, exhibits its potent in vivo anti- tumor activities.

[9]via its high binding affinity for tubulin and improved pharmacokinetic profiles. Cancer Biology \& Therapy. 6:787-794.

[10] Usui, T.; Kondoh, M.; Cui, C-B. ; Mayumi ,T. and Osada,H. (1998). Tryprostatin A, a specific and novel inhibitor ofmicrotubuleassembly,Biochem. J., 333: 543-548.
[11] Boit, H.G.;andEhmke, H. (1955). Chem .Ber. 88: 1590 (Ozeki,S. 1964 Structure OfZephyranthines anew alkaloid isolated from Zephyranthus Candida Herb.

Pharmaceutical Society of Japan. 12 (2): 253254.

[12] Gilman,E.F. (1999). Zephyranthes PP University of Florida Cooperative

extension service, institute of food and Agricultural sciences.

[13] Hayden, W.J. (2007). Atamasco Lily 'ZephyranthesAtamosca". VNPS. Wild flower of the year 2007.

[14] Jennings,T. (2002). Zephyranthes Candida .Inter national water Lily and Gardening Society .www.iwgs.org.

[15] Mohameed, I. H. (2009). Effect of Convolvulus arvensisaquosand alkaloid extract on cancer cell line in vitro and in vivo.Ph.D thesis. University of Baghdad. [16] Cannell, R.J.P.(1998). Natural product isolation, HumanaPress, New Jersey, U.K.

[17] Liberatore, A. M.; Coulomb, H.; Pons, D. et al. (2008).IRC-083927 is a new tubulin binder that inhibits growthof human tumor cells resistant to standard tubulinbindingagents. Mol Cancer Ther.7:24262434.

[18] Lin, C.M.; Singh, S.B.; Chu, P. S.; et al. (1988). Interactionsof tubulin with potent natural and synthetic analogsof the antimitotic agent combretastatin: a structureactivitystudy. Mol Pharmacol.34:200-8.

[19] Jordan, M. A.; Thrower, D. and Wilson, L. (1991). Mechanismof inhibition of cell proliferation by Vincaalkaloids.Cancer Res. 51:2212-2222.

[20] Rose, W. C. (1992). Taxol: a review of its preclinical invivo antitumor activity. Anticancer Drugs;3:311-21.

[21] Hamel E. (1992). Natural products which interact with tubulinin the Vinca domain: maytansine, rhizoxin, phomopsinA, 
Effect of extraction Alkaloids from Zephyranthes candida induces cell death through destruction microtubules in (China hamster cell line) Israa Tareq Aakool AL-Zerkani

dolastatins 10 and 15 and halichondrin $\mathrm{B}$. Pharmacol.Ther. 55:31-51.

[22] Hamel E. (1996). Antimitotic natural products and their interactionswith tubulin. Med Res Rev.16:207-231.

[23] . Dor,r R.T.; Dvorakova, K.; Snead, K.; Alberts, D. S.;Salmon, S. E. and Pettit, G. R. (1996). Antitumor activityof combretastatinA4 phosphate, a natural product tubulininhibitor. Invest New Drugs.14:131137.

[24] Sparreboom, A.; van Tellingen, O.; Nooijen, W.J. and Beijnen,J. H. (1998). Preclinical pharmacokinetics of paclitaxelanddocetaxel. Anticancer Drugs.9:1-17.

[25] Kruczynski, A. and Hill, B.T. (2001). Vinflunine, the latestVinca alkaloid in clinical development. A review of itspreclinical anticancer properties. Crit Rev OncolHematol.40:159-73.

[26] Zhao, X. S.; Song, P. L.; Sun, B.; Jiang, H. C. and Liu, T.F. (2009). Arsenic trioxide inhibits

metastatic

potential ofmousehepatoma $\mathrm{H} 22$ cells in vitro and in vivo. Hepatobiliary Pancreat. Dis. Int. 8: 510-517.

[27] Farombi, E. O. and Owoeye, O. (2011). AntioxidativeandChemopreventive

Properties

of VernoniaamygdalinaandGarciniabiflavonoid. Int. J. Environ. Res. Public Health. 8: 25332555.

[28] Nagappan, T.; Ramasamy, P.; Effendy, M.; Wahid, A.; Segaran,T. C. and Vairappan, C. S. (2012). Biological activityofcarbazole alkaloids and essential oil of murrayakoenigii against antibiotic resistant microbes and cancer cell lines.Molecules : 16. 9651-9664. [29] Jordan, M.A. (2002). Mechanism of action of anti tumordrugs that interact with microtubules and tubulin. Curr.Med. Chem. Anti-Canc. Agents. 2: 1-17. 